\author{
Ingrid Kristine Hasund \\ University of Agder
}

DOI: http://dx.doi.org/10.5617/adno.6599

\title{
Informal language in English L2 writing: What are pupils taught from textbooks?
}

\begin{abstract}
Studies show that intermediate and advanced learners of English overuse informal features in their academic writing, and researchers recommend that instructional material is developed to raise learners' awareness of this overuse. In Norway, little research has been done on younger learners' writing, and no previous study exists of how instructional material such as textbooks deal with informality. The present article investigates how all English textbooks published for lower secondary school under the current curriculum deal with informality in writing.

The findings show that eight out of nine textbooks include instruction on informality. The most frequently mentioned informal features are informal opening/closing phrases and forms of address in letters, contractions, abbreviations, slang, exclamations, and expressions of modality, evaluation and subjective stance, all of which are known from previous research and/or style manuals. The textbook instructions focus on when to use these features and, more importantly, when to avoid them.

Rather unexpectedly, there is little focus on the first person pronoun as an informal feature, which is notable, considering its importance in the literature. First person pronoun usage is, however, a controversial topic, and it is possible that most textbook authors have decided to leave it for later stages. It is also possible that the textbook authors do not consider it an informal feature.

The survey provides a backdrop for future research on pupils' writing by focussing on one aspect of the school context in which this writing is produced, namely the textbooks.
\end{abstract}

Keywords: informal language; English L2 writing, textbook analysis

\section{Uformelt språk i engelsk skriving: Hva sier lærebøkene?}

\section{Sammendrag}

Forskning viser at elever på videregående skole og universitetsstudenter bruker for mange uformelle språktrekk i sin akademiske skriving, og forskere anbefaler 
at det utvikles laremateriell for å heve innlcereres bevissthet om dette temaet. Det er gjort lite forskning i Norge på yngre elevers skriving i engelsk, og det finnes ingen studier av hvordan leremateriell i engelsk, slik som larebøker, behandler temaet uformelt språk. Denne artikkelen undersøker hvordan samtlige engelske larebøker publisert for ungdomsskolen etter Kunnskapsløftet (LK06) behandler temaet uformelle språktrekk i skriving.

Analysen viser at åtte av ni lereverk inkluderer noe instruksjon om uformelt språk. De uformelle trekkene som nevnes oftest er uformelle åpnings- og avslutningshilsner og uformelle tiltaleformer i brev, sammentrukne former, forkortelser, slang, utrop, og uttrykk for modalitet, evaluering og subjektive holdninger, alle vel kjente fra tidligere forskning og/eller fra språkbruksbøker. Lcrebøkenes instruksjoner fokuserer på når det er passende og upassende å bruke disse trekkene i skriftlige tekster.

Noe uventet er det lite fokus på førstepersonspronomenet I som et uformelt trekk, hvilket er påfallende med tanke på hvor sentralt temaet er $i$ forskningslitteraturen. En forklaring kan være at temaet er kontroversielt, og det er mulig de fleste lcerebokforfatterne mener det er for tidlig å behandle det på ungdomsskolen. Det er også mulig at larebokforfatterne ikke anser førstepersonspronomenet for å væere et uformelt trekk.

Studien bidrar med kunnskap som er relevant for framtidig forskning på elevers skriving ved at den fokuserer på ett aspekt ved skolekonteksten som denne skrivingen foregår $i$, nemlig lcerebøkene.

Nøkkelord: uformelt språk, skriving i engelsk som andrespråk/fremmedspråk, larebokanalyse

\section{Introduction}

Research on English second/foreign language (L2) writing in Norway indicates that pupils at upper secondary school (age 16-18) and university levels struggle to adjust their texts to the appropriate level of formality, the main challenge being that they overuse informal features in their formal writing (Hasselgård, 2009; Horverak, 2015; see also Paquot, Hasselgård \& Ebeling, 2013). The tendency towards greater informality in writing has also been noted internationally, among learners as well as experts and in L1 as well as L2 writing (Chang \& Swales, 1999; Granger, 1998). In a recent article on informal features in English academic writing, Hyland and Jiang (2017, p. 40) explore the commonly held perception that "informality has now invaded a large range of written and spoken domains of discourse". Despite the agreement on the trend towards greater informality, there seems to be no consensus on what exactly constitutes informal language, and more research is needed on the topic, which is still "largely unexamined" (Hyland and Jiang, 2017, p. 40). 
In Norway, an awareness of this challenge is reflected in the national subject curriculum for English, the Knowledge Promotion reform of 2006, which states that the pupils' written competence should include "adapting the language to purposeful objectives [...], i.e. by distinguishing between formal and informal written language" (Norwegian Directorate for Education and Training, 2013). The curriculum is currently undergoing a process of renewal to be implemented in 2020. The latest renewal proposal for the subject of English states that pupils at both lower and upper secondary level should be able to write "informal and formal texts", signalling a continued focus on this area in the years to come (Norwegian Directorate for Education and Training, 2019, p. 7, 9, my translation). A continued focus on informality is important in light of the massive input of out-ofschool/extramural English pupils receive through gaming, social media, films, music etc., which to a large extent consists of informal English (Brevik \& Hellekjær, 2018; Sundqvist \& Wikström, 2015).

The above-mentioned studies of English L2 writing in Norway focus on upper secondary and university levels. Very little research has been done on lower secondary pupils' (age 13-16) writing in general (cf. Hasselgren \& Sundet, 2017) and on formality level in particular (but see Thomson, 2018). Also, little is known about what instructions pupils are given regarding formality level. As English L2 teaching in Norway is known to be heavily textbook-centred (Drew \& Sørheim, 2016; Mellegård \& Pettersen, 2012), it seems reasonable to assume that textbooks are a source of information about this topic. As far as I know, no previous study exists on how English textbooks in Norway instruct pupils on the use of informal language in writing - when to use it and, more importantly, when to avoid it. The present study aims to fill this gap by surveying all English textbooks published for lower secondary school after the Knowledge Promotion reform. The research questions are 1) How (if at all) is the term informal used about language in the textbooks? 2) Which language features are explicitly identified as informal? 3) What explicit instructions are provided regarding the use of informal features in writing?

The first research question aims to establish whether the vague term informal, used in both the current curriculum and in the proposals for the new curriculum, is used about language at all in the textbooks, and if so, how it is used to define the concept of informal language. The second question aims to identify a list of features explicitly identified as informal in the textbooks and compare it to previous studies of informal language, to establish whether there is any consensus on what constitutes informal language. The third question investigates how (if at all) textbooks instruct pupils in the use of informal language in writing, in light of the curriculum guidelines and the commonly held perception that young learners tend to overuse such features in academic writing. 


\section{Literature review}

\subsection{What is informality of language?}

The question of what constitutes formality of language (including both formal and informal language) has puzzled researchers for decades. In 1984, Irvine (1984, p. 775) claimed that formality is a term "so general that it is not very useful as an analytic tool", and in 2017, Hyland and Jiang (2017, p. 40) admitted that they found informality to be "a slippery concept, difficult to pin down with a clear definition". What everybody seems to agree on is that informality/formality of language is related to variations between different styles, registers or genres.

Of particular relevance in this context is Biber and his corpus-based studies on register variation in L1 English (e.g. Biber, 1988, 2014; Biber, Conrad, Reppen, Byrd, \& Helt, 2002). According to Biber, different registers can be compared with respect to five dimensions of variation. The most important of these is Dimension 1, which, in Hyland and Jiang's words (2017, p. 42), is "closest to what we understand as informality/formality" ${ }^{1}$. On the "informal" end of Dimension 1 are features marking interpersonal interaction, involved, real-time production circumstances and generalised content; on the "formal" end are features marking high informational density, careful production circumstances and precise lexical choice. Some examples of features which tend to co-occur on the "informal" end of Dimension 1 are private verbs (e.g. think, feel), $1^{\text {st }}$ and $2^{\text {nd }}$ person pronouns (e.g. I, you), WH-questions (e.g. Why is this so?), emphatics (e.g. a lot, really), amplifiers (e.g. absolutely, extremely), hedges (e.g. something like, almost), discourse particles (e.g. well, anyway), contractions (e.g. isn't), possibility modals (can, may, might, could), and independent clause coordination (e.g. sentenceinitial and). Examples of features which tend to co-occur at the "formal" end include nouns, long words, prepositions, high type/token ratio and attributive adjectives (Biber, 1988, pp. 73-75, 104-106, 2014, p. 11, 13; Biber et al., 2002, p. 24).

\subsection{Studies of informality in English L1 expert writing}

In a book chapter entitled "Informal elements in English academic writing: threats or opportunities for advanced non-native speakers?”, Chang and Swales (1999) analysed the following informal elements in research papers across disciplines and in style manuals for professionals and students (see Chang and Swales, 1999, p. 148):

\footnotetext{
${ }^{1}$ Kim and Biber (1994, p. 180) discuss using the label "Informal Interaction Versus Explicit Elaboration" for Dimension 1, which supports Hyland and Jiang's understanding of Dimension 1 as being about informality/formality.
} 
1. The use of the first person pronouns to refer to the author(s) ( $I$ and we) $)^{2}$.

2. Broad reference - anaphoric pronouns (namely, this, these, that, those, it and which) that can refer to antecedents of varying length.

3. Split infinitives, e.g. "The president proceeded to sharply admonish the reporters who asked unanswerable questions."

4. Begin a sentence with - (conjunctions or conjunctive adverb however).

5 . End a sentence with a preposition

6. Run-on sentences and expressions, e.g., "These semiconductors can be used in robots, CD players, etc."

7. Sentence fragments

8. Contractions

9. Direct questions

10.Exclamations

11.Imperatives

Although there is variation between different disciplines, the results overall seem to reflect "tendencies towards informality in current scholarly writing" (Chang \& Swales, 1999, p. 155). In particular, the $1^{\text {st }}$ person pronouns and sentence-initial conjunctions are found to have been "legitimized" to a certain extent. Considering the pedagogical implications for L2 learners, the authors propose that one should raise the learners' rhetorical consciousness with regard to the most common informal features by exposing them to authentic material (Chang \& Swales, 1999, p. 166).

Hyland and Jiang (2017) explore changes in the use of informal language in a corpus of leading journals across disciplines. They define informality in academic writing as "linguistic features which establish a close relationship with readers by realizing a relatively personal tenor which allows writers to make assumptions about a shared context” (Hyland \& Jiang, 2017, p. 43). They use Chang and Swales' (1999) list of informal features, but exclude imperatives and sentence fragments, and add $2^{\text {nd }}$ person pronouns (Hyland \& Jiang, 2017, p. 44). The results show some increase in the use of $1^{\text {st }}$ person pronouns, unattended reference and sentence-initial conjunctions. Overall, however, there is little reason to claim that standards of precision and complexity are losing ground to a more informal and relaxed style. What is changing is rather the rhetorical conventions of academic writing, which increasingly support an involved style where authors position themselves "more explicitly in relation to their ideas and readers" (Hyland \& Jiang, 2017, p. 49). Like Chang and Swales (1999), Hyland and Jiang (2017) emphasize the potential difficulties the trend towards informality creates for L2 learners, who may find it difficult to use informal features appropriately as part of a rhetorical practice to engage with their readers.

2 Examples of features and explanations are only rendered where deemed necessary. 


\subsection{Style manuals aimed at younger writers}

As the studies presented in Section 2.2 focus on advanced students and adults, the present section examines style manuals and usage guides aimed at younger learners, as these are of particular relevance for the present study.

The Little, Brown Handbook Global Edition (Fowler \& Aaron, 2016), aimed at college-level learners, describes informal writing as resembling everyday spoken language "in its colloquial language, contractions and short, fairly simple sentences” (p. 513, 844). Among the features labelled informal are "incomplete sentences, slang, no capital letters, and shortened spellings (...) (e.g. b4 for 'before')" (p. 154). Instructions on formality level in general are variously presented in descriptive (i.e. describing how language is actually used) and prescriptive (i.e. prescribing how language should be used) terms. An example of a more descriptive approach is a section showing how academic writing can vary from "more formal" to "less formal"/"more informal" (p. 153-154). Instructions on informality in particular, however, tend to be more prescriptive. In formal letters or emails to teachers, students are instructed to "always address [the teachers] formally", using formal address terms such as Professor, and to "avoid the shortcuts of texting and tweeting" (p. 156). In academic writing, students are generally instructed to avoid expressions labelled informal or colloquial in dictionaries (p. 513).

Practical English Usage (Swan, 2016), aimed at advanced EFL/ESL students, describes informal language as "mostly used in informal situations", e.g. "in conversation with friends, or emails to one's family" (entry 281). Features labelled informal include contractions and sentence fragments (entry 281), slang, taboo words/swear words and abbreviations (such as cu "see you") (entries 290, 334, 335). In an entry on writing letters, Swan states that informal and personal letters might begin by opening phrases such as "Hi X, Hello X” (entry 290). In terms of instructions, Swan states that he gives descriptive rules, and avoids prescriptive rules except mentioning their existence "where this is useful" (p. ix), e.g. when stating that the imperative form in requests is "not polite" (entry 310). In sum, both Fowler and Aron (2016) and Swan (2016) combine descriptive passages, presenting formality as a scale ranging from more formal to more informal, with some prescriptive passages, presenting the differences in more dichotomous terms, i.e. as either formal or informal.

Bennett's (2009) survey of English academic style manuals reports that many style manual authors recommend "the avoidance of colloquialisms, slang, abbreviations and most phrasal verbs" in English academic discourse (EAD) (Bennett, 2009, p. 50). Although there seems to be a discrepancy between those authors who "insist that academic writing is formal, technical and objective (resulting in the extensive use of Latinate vocabulary and impersonal structures)" and those who "preach simplicity of style (i.e. short direct sentences in the active voice and the use of everyday words)", Bennett does not take this to mean that style manual authors disagree on the overall need for "clarity and precision" in 
EAD (p. 52). The apparent discrepancy has more to do with the level of the target readership: Since "incompetent writers" tend to "lose control of their arguments in their desire to sound sophisticated", some authors insist on simplicity in EAD (p. 52). Bennett therefore concludes that the hegemonic status of conventional EAD still exists, at least in the tradition of English style manuals written for younger students.

\subsection{Studies of written learner corpora}

With the challenges for L2 writers in mind, this section reviews corpus-based studies of learner English, with particular emphasis on the International Corpus of Learner English (ICLE), which consists of texts written by university students of different L1 backgrounds. A pervasive finding is that advanced learners tend to overuse interactional features of writer/reader visibility in their academic written texts, compared to their native peers. Such features include $1^{\text {st }}$ and $2^{\text {nd }}$ person pronouns, private verbs (e.g. think), expressions of modality, evaluation and subjective stance (e.g. you know, I mean, just, really, of course), imperatives and direct questions (see e.g. Ädel, 2006, 2008; Aijmer, 2002; Gilquin \& Paquot, 2008; Granger \& Rayson, 1998; Hasselgård, 2009; Herriman \& Aronsson, 2009; Neff et al. 2004; Paquot, 2010; Paquot et al., 2013; Petch-Tyson, 1998; Recski, 2004; Ringbom, 1998; Thomson, 2018; Virtanen, 1998). Another finding is that the vocabulary of L2 writers is more limited, vaguer and less varied than that of L1 writers. Ringbom (1998, p. 44, 49), for instance, shows that learners from various L1 backgrounds overuse the short verbs think and get and the general nouns people and things. Although none of the learner corpus studies uses the term informal as an overall analytical tool, they regularly use it to characterise learners' academic writing, which is said to have features from "informal talk" (Ringbom, 1998, p. 50) and a style that is "more informal” (Granger \& Rayson, 1998, p. 130). Furthermore, nearly all the above-mentioned features are found in the lists of informal features reported by Chang and Swales (1999) and Hyland and Jiang (2017) (cf. Section 2.2).

An important question is why L2 learners tend to overuse the above-mentioned features in their academic writing. Gilquin and Paquot (2008, p. 57) suggest four possible explanations, which may be seen as interrelated: 1) the influence of spoken English, 2) L1 transfer, 3) teaching-induced factors and 4) developmental factors. Regarding the L1 transfer factor, Paquot et al. (2013, p. 385) suggest that Scandinavian writers possibly "favour a less formal, more interactive writing style”. Hasselgård (2012, p. 64, 67) even suggests that one may talk about "The Norwegian way of writing English" marked by a strong authorial presence, and advises upper secondary teachers to make pupils aware of this "trait of Norwegian writing style" to better enable them to adapt their writing to "purpose, situation and genre”. 


\subsection{Summary and definitions}

The literature review has shown that informality is rather vague as an analytical concept, covering phenomena that are often labelled using terms other than informal, but where informal may be used as a synonym to explain or elaborate on other concepts. Some studies, however, have attempted to define informality as an analytical concept. In my view, the most thorough definition is the one by Hyland and Jiang (2017, p. 43), repeated here for convenience: "[L]inguistic features which establish a close relationship with readers by realizing a relatively personal tenor which allows writers to make assumptions about a shared context”. This definition will be used as a starting point for analysing how (if at all) the term informal is used about language in the textbooks (Research question 1).

The literature review has also shown that there is variation in which specific features are identified as typically informal. The main line of division can be drawn between the corpus-based studies of adult and advanced learner language on the one hand (which include more general features such as contractions and sentence fragments) and the style manuals aimed at younger learners on the other (which include typically adolescent features such as slang and abbreviations and features typical of informal letters). Table 1 sums up the main features identified in the corpus studies as well as some features mentioned in the style manuals: 
Table 1. Informal features mentioned in the corpus studies and style manuals

\begin{tabular}{|l|}
\hline 1st person pronouns \\
\hline 2nd person pronouns \\
\hline Private verbs \\
\hline Phrasal verbs \\
\hline Split infinitives \\
\hline Broad reference - anaphoric pronouns \\
\hline Sentence-initial conjunctions \\
\hline Sentence-final prepositions \\
\hline Run-on sentences and expressions \\
\hline Sentence fragments \\
\hline Contractions \\
\hline Abbreviations \\
\hline Expressions of modality, evaluation and subjective stance \\
\hline Colloquialisms \\
\hline Slang \\
\hline Taboo words \\
\hline Direct questions \\
\hline Exclamations \\
\hline Imperatives \\
\hline Short sentences \\
\hline Simple sentences \\
\hline Informal opening/closing phrases (in letters) \\
\hline Informal forms of address (in letters) \\
\hline
\end{tabular}

The features in this table will be used to code the features identified as informal by the textbook authors (Research question 2).

Finally, the literature review has shown that academic writing has changed slowly over the years to become gradually more informal, but the extent of the change depends on the discipline as well as the age and level of the writers. The corpus studies on L1/adult expert writing show no strong trend towards informality in academic writing; there has indeed been a change of rhetorical practice towards greater writer/reader involvement, but the change is slow. Adding the review of the style manuals, these do not shy away from prescriptive writing instructions, advising learners to avoid informal features in formal writing. In sum, there is little reason to claim that academic standards are losing ground to a more relaxed style. The review of the learner corpus studies, in contrast, shows a somewhat different picture. Among younger university students, overuse of features of writer/reader visibility is a clear tendency. These findings will be used as a starting point for investigating the textbooks' instructions on informality (Research question 3).

\footnotetext{
3 This category includes a wide variety of features, variously labelled as discourse particles/markers hedges, emphatics, amplifiers, intensifiers, hedges, downtoners etc.)

${ }^{4}$ Includes features labelled colloquial, everyday, general and vague language.
} 


\section{Materials and methods}

The materials for the present study consist of nine English textbooks for lower secondary school in Norway. These comprise the total amount of English textbooks published after the 2006 curriculum reform and therefore allow for a comprehensive study of how informality in language is addressed by the textbooks approved for use in Norwegian lower secondary schools. Table 2 gives an overview of the textbooks:

Table 2. Textbook material

\begin{tabular}{|l|l|l|}
\hline Title & Year of publication & Publisher \\
\hline Voices In Time & $2005^{5}-2008$ & Oslo: Cappelen Damm \\
\hline New Flight & $2006-2007$ & Oslo: Cappelen Damm \\
\hline Key & $2006-2008$ & Oslo: Aschehoug \\
\hline Searching & $2006-2008$ & Oslo: Gyldendal \\
\hline Lingua Planet & $2009-2011$ & Oslo: Aschehoug \\
\hline Crossroads & $2013-2015$ & Bergen: Fagbokforlaget \\
\hline Stages & $2013-2015$ & Oslo: Aschehoug \\
\hline Enter & $2015-2018$ & Oslo: Gyldendal \\
\hline Connect & $2016-2018$ & Oslo: Cappelen Damm \\
\hline
\end{tabular}

Each textbook consists of several main components, such as a pupil's textbook, a pupil's workbook and a teacher's book, as well as supplementary materials such as easy/simplified versions of a pupil's textbook, components written for electives and links to external web pages/resources. However, only the main components have been included in the analysis. The Appendix gives a complete list of all textbook components and the abbreviations that are used to report the findings. K8-PT, for instance, refers to Key year 8 pupil's textbook, whereas E8-10-BS refers to Enter's component Basic skills, which covers years 8, 9 and 10. Each printed book was counted as one component. Counting digital components is more challenging due to the many options for organising content online. For practical purposes, each digital resource was counted as three components, one for each school year. In total, the analysis spans 100 different components.

One way to investigate informality, according to Hyland and Jiang (2017, p. 43), is to survey style guides, which "reflect something of the concerns and thinking of teachers, students and practitioners". English textbooks are not style guides per se, but they do contain style guide sections, and it is the explicit advice on informality given in these sections that constitutes the focus in the present study. From the literature review, it is evident that the notion of informality can be described using terms other than informality, and it is possible that the textbook authors would use terms such as private and casual instead of informal as a superordinate term. In the present study, however, one of the aims is to establish whether the term informal, as used in the English curriculum, is adopted by the

${ }^{5}$ Published 2005 but written for the 2006 curriculum. 
textbook authors; i.e. whether it seems to work as a useful term in writing instruction. Therefore, to identify the relevant sections on informality across the 100 components, it was decided to search for variants of the term informal (in English and, since English textbooks tend to include sections written in Norwegian, variants of the corresponding Norwegian term uformell) and to study which definitions and synonyms were used to describe the term, rather than searching for a list of possible synonyms and try to identify the extent to which these related to the notion of informality. Evidently, limiting the search to variants of the term informal challenges the validity of the analysis, as it captures only what the textbooks have to say about the term informal, including related synonyms such as private/casual and language features such as contractions when these are explicitly labelled 'informal'. It does not capture everything the textbooks have to say about e.g. private/casual language or contractions when these are not explicitly defined as informal. On the other hand, choosing informal as the search term enables the analysis of a large amount of data, which strengthens the validity in allowing for a comprehensive study of all textbooks for lower secondary available in present-day Norway.

The first step in the analysis consisted of scanning the textbooks that are only available in print (see Appendix) for variants of the terms informal in English and uformell in Norwegian. The digital textbooks/online resources were then analysed using an electronic search for the string informal* in English and uformel* in Norwegian, yielding all inflected and derived forms (e.g. informal, informally, informality in English and uformell, uformelt, uformelle in Norwegian). Having extracted all hits on the search terms across the 100 components, each hit was studied in context and irrelevant hits, such as informal dress, were excluded. The hits were then extracted with the relevant context (a sentence or paragraph) and copied into a separate Word document. The document was used as a basis for answering Research question 1 and 3 on the use of the term informal, the definitions and instructions provided, and discussing them in light of previous research. The analysis of Research question 3 was structured around the descriptive/prescriptive and scale/dichotomy approaches to informality identified in the literature. Regarding Research question 2 about which language features were mentioned, all features explicitly identified as "informal" by the textbooks were entered into an Excel spreadsheet and coded using the 23 features in Table 1.

\section{Findings}

\subsection{How (if at all) is the term informal used about language in the textbooks?} The aim of Research question 1 was to establish whether the term informal is used about language at all in the textbooks, and if so, how it is used to define the concept of informal language. The analysis showed that all nine textbooks apply 
the term informal in relation to language use. It also showed that all textbooks except New Flight use the term informal in relation to the superordinate concept of formality level, describing informal language in relation to what it is not, i.e. formal language. The following excerpt from Stages illustrates how the term informal is used as part of a formal-informal distinction in the eight textbooks:

\title{
Formal and informal language Formelt og uformelt språk
}

\begin{abstract}
Vi bruker formelt eller uformelt språk avhengig av situasjonen og hvem vi skriver for eller snakker til. Bruk formelt språk i seriøse skriftlige tekster og i situasjoner der du skriver for eller snakker til mennesker du ikke kjenner godt. Uformelt språk er mer vanlig i personlige brev og meldinger, og i dagligdagse samtaler med slekt og venner. Her er noen generelle kjennetegn ved formelt og uformelt språk på engelsk:
\end{abstract}

\section{Formal}

- Unngå verbsammentrekninger: She will not be there.

- Unngå partikkelverb: discover, examine

- Lengre, komplekse setninger

- Lengre ord av latinsk eller gresk opprinnelse: cuisine, terminate

- Would og could vanlig I spørsmål og forslag: Could you please help me? I would suggest we leave shortly.

- Høflighetsfraser: with all due respect
Informal

- Verbsammentrekninger: She wont be there.

- Partikkelverb: find out, look at

- Korte, enkle setninger

- Korte ord av anglosaksisk opprinnelse: food, end

- Will, can og imperativformen vanlig I spørsmål og forslag: Can you help me? Let's go now.

- Slang og fyllord: $I^{\prime} m$ chuffed to bits. Well, kind of, like, etc.

Figure 1. Excerpt from Stages (ST10-PB, p. 306)

Figure 1 shows a section entitled "Formal and informal language", with an introductory paragraph on formality level followed by a table with formal and informal features. In the introductory paragraph, formality level is defined as "dependent on the situation and who we write for or speak to". The other textbooks provide similar definitions, e.g. Enter, which states that formality level "depends on the setting" (E8-10-BS, p. 117) and "text type" (E8-10-BS, p. 84). In sum, formality of language is described across the textbooks as depending on the situation and setting and as varying according to purpose, topic or text type.

As mentioned, New Flight provides no overall definition of formality level using the terms formal/informal. It has a section on how to write "formal letters" (N10-PW, pp. 176-179), which includes examples of what could be labelled both formal and informal letters; here the word formal is used but not informal. In fact, the word informal occurs only once in this textbook, where the style of Australian English is described as "quite informal" (N8-PW, p. 204). With the exception of formal letters, New Flight prefers to describe language variation related to purpose 
and situation using terms other than formal and informal, such as polite (N8-PW, p. 86), factual "saklig”, personal (N8-TB, p. 18) and everyday language (N10PW, p 148).

Across the other eight textbooks, nine characteristics are used to define informal language. These are listed in Table 3 with a selection of quotes to illustrate. The abbreviation IF refers to "informal" and $\lg$ refers to "language".

Table 3. Characteristics of informal language described in the textbooks

\begin{tabular}{|c|c|}
\hline Characteristic of informal language & Selection of textbook quotes ${ }^{6}$ \\
\hline Used in everyday conversations & $\begin{array}{l}\text { IF lg is the same as "everyday language" } \\
\text { (CR10-PW, p. 122). }\end{array}$ \\
\hline Relaxed, casual & $\begin{array}{l}\text { Informal is defined as "relaxed or casual" } \\
\text { (V9-PT, p. 24). }\end{array}$ \\
\hline Unceremonious & $\begin{array}{l}\text { Informal is defined as "unceremonious" } \\
\text { ("uhøytidelig") (CO8-PB, p. 193). }\end{array}$ \\
\hline Friendly & $\begin{array}{l}\text { "Informal letters" are written in "a friendly } \\
\text { tone" (SE8-PB, p 30). }\end{array}$ \\
\hline Private & $\begin{array}{l}\text { In IF invitations, “the sender is private” (L8- } \\
\text { TD, Breaktime, Løp 2, invitations). }\end{array}$ \\
\hline Personal & $\begin{array}{l}\text { "Informal writing" is described as "personal } \\
\text { messages" (K8-PT, p. 101). }\end{array}$ \\
\hline Used with people one knows well & $\begin{array}{l}\text { IF lg is used in "messages to someone you } \\
\text { know well" (V9-PW, p. 8). }\end{array}$ \\
\hline Related to generational differences & $\begin{array}{l}\text { "The use of formal and informal written } \\
\text { language in invitations is related to (...) } \\
\text { generational differences (old/young)" (L8- } \\
\text { TD, Breaktime, Løp 2, invitations). }\end{array}$ \\
\hline Oral style & $\begin{array}{l}\text { In an IF email to friends, the "tone can be } \\
\text { rather oral" ("muntlig") (L9-PD, Film). }\end{array}$ \\
\hline
\end{tabular}

Summing up, informal language is described as used in everyday conversations, it is relaxed/casual, unceremonious, friendly and private; it is used in texts that are personal and addressed to people one knows well; it is related to generational differences, being more often used among younger people, and is typical of an oral style.

\subsection{Which language features are explicitly identified as informal?}

The aim of Research question 2 was to identify a list of features explicitly identified as informal by the textbook authors and compare it to the list of informal features identified in the literature. Thus, the next step in the analysis was to study the hits on the search terms in context; a total of 16 informal language features were extracted and coded using the labels from Table 1 . The results are shown in Table 4 with a selection of quotes to illustrate examples and/or descriptions. The

\footnotetext{
${ }^{6}$ Some quotes are originally in Norwegian; I have translated these without giving the original due to space limitations and readability, except in a few cases where the English translation is not entirely straightforward.
} 
table is sorted by dispersion, with the feature mentioned by the most textbooks on top, and the other features in decreasing order.

Table 4. Language features described as informal in the textbooks

\begin{tabular}{|c|c|c|}
\hline Feature & $\begin{array}{l}\text { Number of } \\
\text { textbooks }\end{array}$ & Textbook quotes (examples and/or descriptions) \\
\hline $\begin{array}{l}\text { Informal } \\
\text { opening/closing } \\
\text { phrases (in letters) } \\
\end{array}$ & 8 & $\begin{array}{l}\text { "Hi/dear” and “with love from” (SE10-PB, p. 96); } \\
\text { "Hi!, Hello! What’s happening?” and “See you } \\
\text { (later), See ya!, Bye!” (L9-PD Breaktime Writing 2). }\end{array}$ \\
\hline Contractions & 8 & $\begin{array}{l}\text { Contractions are "often used in spoken English and } \\
\text { in informal texts" (E8-PB, p. 147) }\end{array}$ \\
\hline $\begin{array}{lr}\text { Informal forms } & \text { of } \\
\text { address (in letters) } & \end{array}$ & 7 & $\begin{array}{l}\text { "Informal texts like personal letters" begin with the } \\
\text { first name of the addressee, e.g. "Dear Sarah" (K8- } \\
\text { PT, p. 216). }\end{array}$ \\
\hline Abbreviations & 7 & $\begin{array}{l}\text { LOL, L8R (L10-PD, Science: write: formal email), } \\
\text { cos “because” and slo-mo "slow motion” (E9-PB, p. } \\
221) .\end{array}$ \\
\hline Slang & 6 & $\begin{array}{l}\text { A biggie "important" (E8-PB, p. 47) and sick "very } \\
\text { good" (CR8-10-PD Exercises > grammar). }\end{array}$ \\
\hline Exclamations & 6 & $\begin{array}{l}\text { "Why is fantasy so insanely popular? It doesn't } \\
\text { matter! Let's just be glad that it is!” (E10-PB, p. 158, } \\
\text { E10-TB, p. 159). }\end{array}$ \\
\hline $\begin{array}{l}\text { Expressions of } \\
\text { modality, evaluation } \\
\text { and subjective stance }\end{array}$ & 5 & $\begin{array}{l}\text { Words/expressions such as "Well, kind of, like, etc.” } \\
\text { (ST10-PB, p. 306); informal modals, e.g. “Can you } \\
\text {...?” in requests (K9-TB, p. 72). }\end{array}$ \\
\hline Sentence fragments & 4 & "I love fantasy. Always did.” (E10-PB, p. 156). \\
\hline Imperatives & 3 & $\begin{array}{l}\text { "Hand me the screwdriver, Sarah!” (K9-TD, chapter } \\
\text { test unit 2). }\end{array}$ \\
\hline Colloquialisms & 3 & $\begin{array}{l}\text { Buddy (K8-TD, Task formal vs informal language); } \\
\text { stuff like that (E8-PB, p. 47), “food, end” (ST10-PB, } \\
\text { p. 306). }\end{array}$ \\
\hline 1st person pronouns & 2 & $\begin{array}{l}\text { An opinion piece is written in an "informal, first- } \\
\text { person voice" (CO9-TB: 236); a diary entry should } \\
\text { be written using "informal language" and "a } \\
\text { personal point of view ( } 1^{\text {st }} \text { person: "I")" (V9-PW, p. } \\
6) \text {. }\end{array}$ \\
\hline phrasal verbs & 2 & Find out, look at (ST10-PB, p. 306). \\
\hline Short sentences & 2 & “Shorter sentences” (E8-10-BS, pp. 84-85). \\
\hline Simple sentences & 1 & “Simple sentences” (ST10-PB, p. 306). \\
\hline $\begin{array}{l}\text { Sentence-initial } \\
\text { conjunctions }\end{array}$ & 1 & $\begin{array}{l}\text { Sentence-initial "coordinating linking words and } \\
\text { and but" (V10-PD, ch. } 7 \text {, fact sheet 54, linking } \\
\text { words). }\end{array}$ \\
\hline Taboo words & 1 & “Swearing” (E8-10-BS, p. 84-85). \\
\hline
\end{tabular}

Many of these features are relatively straightforward and need no further comment. The remainder of this section will focus on the features that need some more explanation, or that are of particular interest for the discussion (Section 5). 
The two features informal opening/closing phrases and informal forms of address stand out from the rest because they have a more restricted area of usage, dealing specifically with politeness conventions in letters. The main reason why these two features rank high up in Table 4 is the strong association of the concept of formality with writing letters. The textbooks vary as to how much they compare and contrast formal letters to informal letters, but all textbooks include at least one section on formal letters. As mentioned, even New flight, which rarely uses the word formal, has a section on "formal letters".

The other 14 features from Table 4 are not restricted to the context of letters but are more general. As regards the category expressions of modality, evaluation and subjective stance, no textbook uses this technical label. Instead, the Norwegian words "småord" (smallwords) and "fyllord" (verbal fillers) are generally accepted as everyday terms for several words in this category (see e.g. Svennevig and Hasund 2018, p. 138, 151). Crossroads, for instance, uses the term "småord" (CR10-WB, p. 122) and Stages uses "fyllord" (ST10-PB, p. 306). The category also includes modal auxiliaries. In Key, pupils are instructed to "use the modal auxiliaries to adjust the language to the appropriate formality level" (K9TB, p. 72), e.g. in requests, where "Can you ...?" is described as informal and contrasted with "Could you ...?” which is more formal and polite (K9-PT, p. 51).

The feature colloquialisms comprises expressions described as "colloquial", e.g. buddy (K8-TD, Task formal vs informal language), "vague expressions" such as stuff like that (E8-PB, p. 47), and "short words of Anglo-Saxon origin, e.g. food, end", in contrast to "longer words of Latin or Greek origin, e.g. cuisine, terminate" (ST10-PB, p. 306).

The feature $1^{\text {st }}$ person pronoun was counted only when the textbooks made an explicit link between informality and the $1^{\text {st }}$ person pronoun (Connect and Voices in time). Searching states that the language in information texts uses the "third person" and an "impersonal, formal tone" (SE8-TB, p. 78), which by implication could be taken to mean that the $1^{\text {st }}$ person pronoun is more personal and informal. However, no explicit link is made in this textbook between the use of the $1^{\text {st }}$ person and informality and it was therefore not included in the count. New Flight explains that a reader's letter is "written in $I$ - our you-form" and that "the language is personal”, but this is not explicitly classified as informal (N8-TB, p. 18). The $1^{\text {st }}$ person pronoun will be further discussed in Section 5.2.3.

\subsection{What explicit instructions are provided regarding the use of informal features in writing?}

The final step in the analysis was to identify what instructions the textbooks provide regarding informality in writing (Research question 3), both instructions on usage and specific tasks for pupils to work with. Again, the starting point was to study the hits on the term informal in context. Instructions on usage and tasks explicitly linked to informality were identified and analysed in relation to the 
descriptive-prescriptive approach and the scale-dichotomy approach presented in Sections 2.3 and 3.

\subsubsection{Instructions on usage}

The eight textbooks which define informality using the term informal tend to combine a descriptive and a prescriptive approach in their instructions on usage. While a more descriptive approach is often used in definitions and descriptions of informality, a more prescriptive approach tends to be adopted in the explicit writing instructions, especially instructions on when to avoid informal language. The descriptive approach presents the formal-informal distinction as a scale ranging from more formal to more informal, whereas the prescriptive approach tends to present the formal-informal distinction as a dichotomy (either formal or informal).

As the textbook instructions are rather similar across the various language features listed in Table 4, the following presentation will focus on contractions as a case in point. As the table shows, the feature contractions is mentioned in eight out of nine textbooks (again, New flight is the exception) and seems to have an almost iconic status as a marker of informal language. Crossroads has a section on formal and informal language in all workbooks (year 8-10) which states that "a hallmark of informal language" is the use of "many contracted forms" (CR8PW, p. 138), and that contracted forms "are little used" in formal written language (CR9-PW, p. 117). Similarly, Enter states that contractions are "often used in spoken English and in informal texts" (E8-PB, p. 147); both examples show how the textbook authors adopt a descriptive/scale approach in their presentation.

The instructions on how to write texts, however, tend to follow a prescriptive/dichotomy approach, as shown in the lists of advice in Crossroads and Stages: "Do not use contracted forms (...) when you write letters to the editor, letters to people you do not know or argumentative texts" (CR10-PW, p. 122), and "Formal language: Avoid contracted verb forms" (ST10-PB, p. 306). Voices in time, however, takes a somewhat different approach in its style guide on contractions:

"Contractions can make serious writing too informal; therefore you should try to avoid too many contractions in formal writing. (...) However, you can use some of the most common contractions even in formal writing, such as it's, you're, you've, don't, couldn't, what's, there's. The main point is not to overuse contractions." (V10-PD, ch. 1 , fact sheet 32).

The quote shows that Voices in time opens up for a certain amount of contractions in formal writing, even in the prescriptive style guide. By and large, however, the textbooks tend to instruct pupils to avoid contractions altogether in formal writing. 


\subsubsection{Tasks}

The textbooks include a variety of tasks on informal language, usually linked to the formal-informal distinction. In Crossroads, there is a set of online, selfcorrecting exercises on "formal and informal language" (CR8-10-PD, Exercises $>$ Grammar). One task states that slang is used "only in spoken language and informal texts" and asks the pupils to determine which of the three expressions is not a slang word: "That song is sick/cool/very good!”; the correct answer is "very good”. This is a closed question which tests the pupils' receptive knowledge (i.e. understanding). Another closed, self-correcting question tests the pupils' productive knowledge by asking them to rewrite the sentence "You are going to do just fine" so that "the language becomes informal" (the correct answer is "You're gonna do just fine"). Several of the printed textbook components include similar closed questions which test the pupils' receptive and productive knowledge of the difference between formal and informal texts. Enter, for instance, has a task where pupils are asked to study a formal and an informal version of a text and then "match the informal language from the text with the more formal version"; examples of correct answers here are teens vs teenagers and kids vs children (E8-PB, p. 47).

Other tasks involve open questions which ask pupils to demonstrate their knowledge of formality level more generally, e.g. "Explain differences between formal and informal language" (K10-PT, p. 116) and "Demonstrate that you know the difference between formal and informal language" (E10-PB, p. 250). Some tasks ask pupils to identify features in specific texts and use the results to reflect on formality level more generally. Connect, for instance, presents a diary entry and suggests the following tasks in the teacher's book: "Talk about the differences between formal and informal writing. (...) How can the students tell that 'Dear Diary' is an informal text?” (CO8-TB, p. 135).

Even more challenging tasks are those which ask pupils to write texts that are both formal and informal, or to reflect more generally on why we use formal and informal language in different situations and text types. Key has a task where pupils are asked to write two versions of the same email, one "funny and informal" and one "very formal" (K8-PW, p. 37). The teacher's book suggests that this task "can be a starting point for discussing language use and context. What is appropriate when? How do we write to whom?” (K8-TB, p. 83).

Summing up, three types of instruction were found in the textbooks: 1) more complex descriptive practices, describing formality as a scale ranging from more formal to more informal; 2) simplified prescriptive rules stated in more dichotomous terms, where advice on when to avoid informal features is especially prominent; and 3) various tasks, from closed tasks asking pupils to choose between formal and informal features, with only one correct answer (prescriptive/dichotomy), to open tasks asking pupils to produce their own texts, reflect on what formality of language is and discuss when more formal or more informal language is typically used (descriptive/scale). From a didactic 
perspective, this variation allows for differentiation, accommodating to pupils' individual level of competence.

\section{Discussion}

\subsection{Is informal a useful term?}

Research question 1 aimed to establish whether the term informal is used about language at all in the textbooks, and if so, how it is used to define the concept of informal language. Asking this question makes sense in light of the fact that the term is used both in the current English subject curriculum and in the proposals for the new curriculum (cf. Section 1). It also makes sense in light of previous research, which shows that the concept of informality is so general that it is rarely used in research as an analytical tool, with the studies by Chang and Swales (1999) and Hyland and Jiang (2017) as notable exceptions. To the extent that the term is used at all in research, it is primarily to characterise other, superordinate concepts (e.g. Hasselgård, 2009, p. 136; Kim \& Biber, 1994, p. 180; Petch-Tyson, 1998, p. 110; Recski, 2004, p. 2). The style manuals are less reluctant to use informal as a superordinate term, probably because their target group includes non-professional and younger writers, to whom the everyday term informal is both familiar and sufficiently clear (e.g. Swan, 2016, entry 281, 333).

The analysis showed that all textbooks except one, New Flight, use the term informal systematically as part of a formal-informal distinction, thus responding to the requirement in the curriculum that pupils should be able to distinguish between formal and informal language (Norwegian Directorate for Education and Training, 2013). The term informal is not further defined in the curriculum, and the textbooks might have chosen to operationalise it using other terms. However, only New Flight has chosen such an approach, preferring terms such as personal and everyday language. In sum, most of the textbook authors seem to share the view of style manual authors and the authors of the current and new English subject curricula that the term informal, despite its obvious fuzziness, is useful in textbooks aimed at younger learners.

Across the eight textbooks that define formality in relation to a formalinformal distinction in general, nine specific characteristics were used to define informal language in particular: Informal language is used in everyday conversations, it is relaxed/casual, unceremonious, friendly and private; it is used in texts that are personal and addressed to people one knows well; it is related to generational differences and is typical of an oral style. Compared to Hyland and Jiang's (2017) definition of informality, which was chosen for the present study and which includes the notions of a close relationship between participants and a shared context which allows for a personal tenor, the textbook definitions can be said to "translate" these notions into everyday language aimed at younger learners. The point about generational differences, for instance (i.e. that informal 
language is more often used among younger people), is not mentioned by Hyland and Jiang (2017), but fits in with their notion of a close relationship, allowing young learners to assume a shared context with their peers and to adopt a personal tenor.

\subsection{Is there any consensus regarding "typically informal” language features and their usage?}

This section discusses the findings from Research question 2 and 3 in relation to previous studies, focusing on three aspects of the findings that are of particular interest. Section 5.2.1 discusses the textbooks' emphasis on letter writing as a way of introducing pupils to formality of language. Section 5.2.2 addresses the prominence of some more general informal features of particular relevance for younger learners. Section 5.2.3 discusses the lack of focus in the textbooks on the $1^{\text {st }}$ person pronoun as an informal feature, which is noteworthy considering its prominence in the literature.

\subsubsection{Letter writing}

As mentioned, the two features informal opening/closing phrases and informal forms of address stand out from the rest not just because they are so prominent, but also because their usage is restricted to the context of writing letters. There seems to be a general consensus among the textbook authors that writing letters is an excellent way of introducing pupils to the concept of formal and informal language. Usage of forms of address and opening/closing phrases in letters appear to be very "teachable" topics, where the stylistic choices are rather straightforward and clearly marked for degree of formality and politeness, e.g. the choice between starting a letter with Dear Ms Johnson or Hi Sarah! This is in line with the style manuals aimed at younger learners (e.g. Fowler \& Aaron, 2016; Swan, 2016), which include specific instructions regarding formality and politeness conventions in letters, for instance how students should address their teachers so as not to appear rude or impolite. The corpus studies, in contrast, do not include forms of address or opening/closing phrases in their frequency counts (e.g. Biber, 1988, 2014; Chang \& Swales, 1999; Hyland \& Jiang, 2017), as these features are rather infrequent in written texts other than letters. Biber (1988, p. 8), however, does state that "[v]ariation in address terms, such as Dr Jones versus Sue, functions to mark the formality of the situation and the social role relationship between speaker and listener". Seeing how the two features opening/closing phrases and forms of address so nicely capture some of the central elements of formality, it should come as no surprise that they figure so prominently in the textbooks.

\subsubsection{General informal language features and younger learners}

Apart from the two features associated specifically with letter writing, all other features in Table 4 are more general and not restricted to a particular area or 
context. Of these, the following are particularly prominent: contractions, abbreviations, slang, exclamations and expressions of modality, evaluation and subjective stance. With the exception of abbreviations and slang, these features are all included in several corpus studies as well as in style manuals, cf. Section 2. Abbreviations and slang have received very little attention in corpus-based studies (cf. Sections 2.2 and 2.4), probably because they are less common among older writers. They are, however, mentioned in the style manuals aimed at younger learners (Bennett, 2009; Fowler \& Aaron, 2016; Swan, 2016), and their prominence in the textbook data indicates that they are highly relevant in instructions on formality at lower secondary level.

\subsubsection{Writer/reader visibility features: The 1st person pronoun}

While Sections 5.2.1 and 5.2.2 discussed the most prominent features in the textbook data, this section discusses one of the least prominent features, notably the $1^{\text {st }}$ person pronoun. Considering the attention this feature has been given in corpus-based studies as well as style manuals, it is noteworthy that it is classified as an informal feature by only two textbooks. One explanation could be that the textbook authors generally seem to agree that using or avoiding the $1^{\text {st }}$ person pronoun in formal, academic writing has been and continues to be "the perennial topic of debate" among scholars, students and others (Chang \& Swales, 1999, p. 163, cf. also Hyland \& Jiang, 2017), and perhaps most of the textbook authors consider the topic so controversial that they leave it for later stages. The question is whether avoiding the topic is doing the pupils a disservice. As shown in the studies by Chang and Swales (1999) and Hyland and Jiang (2017), the $1^{\text {st }}$ person pronoun has been "legitimized" in formal, academic writing to a certain extent, but there is considerable variation between different disciplines. This variation may create difficulties for L2 learners, and Chang and Swales propose that one should raise the rhetorical consciousness of L2 learners with regard to the most common informal features (Chang \& Swales, 1999, p. 166). The question is at which level this should start. Hasselgård (2012, p. 64) suggests that teachers in upper secondary school should make the pupils aware of "The Norwegian way of writing English”, marked by a strong authorial presence. Perhaps most textbook authors regard lower secondary school as too early.

Another explanation for the lack of focus on the $1^{\text {st }}$ person pronoun may be that the textbook authors do not consider it a feature of informality. In instructions on how to write letters, for instance, pupils are advised to express their own opinion and be visible authors in both informal and formal letters. New Flight discusses the use of the $1^{\text {st }}$ person pronoun in reader's letters as personal, not informal (N8-TB, p. 18), which means that it was not included in the count of informal features in the present study. Similarly, Voices in time states that both formal and informal letters and e-mails are "written from a personal point of view (1st person: I or we)" (V10-PW, p. 8), cf. Biber's (1988, p. 71) description that professional letters "are structured like academic prose (...), but they are directed 
towards individuals, require concern for the interpersonal relationship" and "enable a relatively high degree of interaction between participants". More research is needed to establish the extent to which textbooks avoid discussing the stylistic effect of the $1^{\text {st }}$ person pronoun or whether they discuss it primarily using labels other than informal. More research is also needed on other features of writer/reader visibility, which were mentioned only rarely or not at all in the textbooks.

\section{Conclusion}

Having analysed all English textbooks published for lower secondary school in Norway after the Knowledge Promotion reform of 2006, the present study has shown that eight out of nine textbooks include instructions on the topic of informality in writing - when to use it and, more importantly, when to avoid it. In other words, eight textbooks respond to the requirement in the English subject curriculum that pupils should be able to distinguish between formal and informal language, and they do so by using the terms formal and informal. A continued focus on informality is important in light of the massive input of informal English pupils receive from out-of-school/extramural English, and the distinction between formal and informal language is included in the latest renewal proposals for the new subject curriculum to be implemented in 2020.

One question which arises from this study is: To what extent can teachers in upper secondary school expect pupils to be able to distinguish between formal and informal language after lower secondary? Seeing how much the textbooks vary in their treatment of informality, the answer depends on which textbooks are used and how the teachers use them; it also depends on a number of other factors beyond the instructional setting. Evidently, a textbook study cannot reveal how teachers actually teach, and more research is needed on this aspect of writing instruction. Mixed-method studies involving classroom observations and interviews, for instance, could provide knowledge of the extent to which informality of language is in fact being taught in the classroom.

Finally, the present study also has implications for research on learner writing. The textbook analysis has shown that a total of 16 different language features are labelled informal by the textbook authors, and future studies of young learner writing could carry out investigations of one or more of these features. More generally, the study adds to the growing pool of knowledge about informality in learner writing by focussing on one aspect of the school context in which this writing is produced, namely the textbooks.

\section{Acknowledgements}

I would like to thank two anonymous reviewers for their helpful suggestions and comments to an earlier version of the manuscript. 


\section{About the author}

Ingrid Kristine Hasund is Associate Professor of English Language and head of the research group ESIT (Elevspråk i transitt “Pupils' language in transit”), which studies pupils' written development in L2 English and L3 German, French and Spanish in Norway. She has done research on discourse markers, slang and swearing in informal English and Norwegian teenage language.

Institutional Affiliation: Department of Foreign Languages and Translation, University of Agder, P. O Box 422, 4604 Kristiansand.

Email: kristine.hasund@uia.no

\section{References}

Ädel, A. (2006). Metadiscourse in L1 and L2 English. Amsterdam: John Benjamins.

Ädel, A. (2008). Involvement features in writing. Do time and interaction trump register awareness? In G. Gilquin, S. Papp, \& M. B. Díez-Bedmar (Eds.), Linking up contrastive and learner corpus research (pp. 35-53). Amsterdam: Rodopi.

Aijmer, K. (2002). Modality in advanced Swedish learners' written interlanguage. In S. Granger, J. Hung, \& S. Petch-Tyson (Eds.), Computer learner corpora, second language acquisition and foreign language teaching (pp. 55-76). Amsterdam: John Benjamins.

Bennett, K. (2009). English academic style manuals: A survey. Journal of English for academic purposes, 8(1), 43-54. doi: https://doi.org/10.1016/j.jeap.2008.12.003

Biber, D. (1988). Variation across speech and writing. Cambridge: Cambridge University Press.

Biber, D. (2014). Using multi-dimensional analysis to explore cross-linguistic universals of register variation. Languages in contrast, 14(1), 7-34. doi: https://doi.org/10.1075/lic.14.1.02bib

Biber, D., Conrad, S., Reppen, R., Byrd, P., \& Helt, M. (2002). Speaking and writing in the university: A multidimensional comparison. TESOL Quarterly, 36(1), 9-48. doi: https://doi.org/10.2307/3588359

Brevik, L. M., \& Hellekjær, G. O. (2018). Outliers: Upper secondary school students who read better in the L2 than in L1. International journal of educational research, 89, 80-91. doi: https://doi.org/10.1016/j.ijer.2017.10.001

Chang, Y.-Y., \& Swales, J. (1999). Informal elements in English academic writing: Threats or opportunities for advanced non-native speakers? In C. N. Candlin \& K. Hyland (Eds.), Writing: texts, processes and practices (pp. 145-166). London: Longman.

Drew, I., \& Sørheim, B. (2016). English teaching strategies: Methods for English teachers of 10 to 16-year-olds (3rd ed.). Oslo: Samlaget.

Fowler, H. R., \& Aaron, J. E. (2016). The little, brown handbook, global edition (13th ed.). Harlow, UK: Pearson Education Limited.

Gilquin, G., \& Paquot, M. (2008). Too chatty: Learner academic writing and register variation. English text construction, 1(1), 41-61.

Granger, S. (1998). The computer learner corpus. In S. Granger (Ed.), Learner English on computer (pp. 3-18). London: Longman.

Granger, S., \& Rayson, P. (1998). Automatic profiling of learner texts. In S. Granger (Ed.), Learner English on computer (pp. 119-131). London: Longman. 
Hasselgård, H. (2009). Thematic choice and expressions of stance in English argumentative texts by Norwegian learners. In K. Aijmer (Ed.), Corpora and language teaching (pp. 121-140). Amsterdam: John Benjamins.

Hasselgård, H. (2012). Den norske måten å skrive engelsk på ['The Norwegian way of writing English']. Bedre skole, 1, 64-67.

Hasselgren, A. \& Sundet, K.T. (2017). Introducing the CORYL Corpus: What it is and how we can use it to shed light on learner language. Bergen language and linguistics studies, 7. doi: https://doi.org/10.15845/bells.v7i0.1107

Herriman, J., \& Aronsson, M. B. (2009). Themes in Swedish advanced learners' writing in English. In K. Aijmer (Ed.), Corpora and language teaching (pp. 101-120). Amsterdam: John Benjamins.

Horverak, M. O. (2015). English writing instruction in Norwegian upper secondary schools. Acta didactica Norge, 9(1), 1-20 (Article 11). doi: https://doi.org/10.5617/adno.1689

Hyland, K., \& Jiang, F. (2017). Is academic writing becoming more informal? English for specific purposes, 45, 40-51.

Irvine, J. T. (1984). Formality and informality in communicative events. In J. Baugh \& J. Sherzer (Eds.), Language in use: readings in sociolinguistics (pp. 211-228). New Jersey: Prentice-Hall.

Kim, Y.-J., \& Biber, D. (1994). A corpus-based analysis of register variation. In D. Biber \& E. Finegan (Eds.), Sociolinguistic perspectives on register (pp. 157-181). Cary, US: Oxford University Press.

Mellegård, I., \& Pettersen, K. D. (2012). Curriculum practice: English teachers' understanding and realisation of the new national curriculum, LK06. In A. Hasselgren, I. Drew, \& B. Sørheim (Eds.), The young language learner: Research-based insights into teaching and learning (pp. 207-218). Bergen: Fagbokforlaget.

Neff, J., Ballesteros, F., Dafouz, E., Díez, M., Martínez, F., Prieto, R., \& Rica, J. P. (2004). The expression of writer stance in native and non-native argumentative texts. In R. Facchinetti \& F. Palmer (Eds.), English modality in perspective: Genre analysis and contrastive studies (pp. 141-161). Frankfurt am Main: Peter Lang.

Norwegian directorate for education and training. (2013). English subject curriculum (revised 2013). Retrieved 28 November 2017, from www.udir.no/kl06/ENG103?lplang=http://data.udir.no/kl06/eng

Norwegian directorate for education and training. (2019). Læreplan i engelsk. Høringsutkast, Fagfornyelsen [English subject curriculum. Consultation draft, Subject renewal]. Retrieved 29 July 2019, from https://hoering.udir.no/Hoering/v2/338?notatId=674

Paquot, M. (2010). Academic vocabulary in learner writing: From extraction to analysis. London: Continuum.

Paquot, M., Hasselgård, H., \& Ebeling, S. O. (2013). Writer/reader visibility in learner writing across genres: A comparison of the French and Norwegian components of the ICLE and VESPA learner corpora. In S. Granger, G. Gilquin, \& F. Meunier (Eds.), Twenty years of learner corpus research: Looking back, moving ahead. Corpora and language in use - Proceedings 1 (pp. 377-387). Louvain-la-Neuve: Presses universitaires de Louvain.

Petch-Tyson, S. (1998). Writer/reader visibility in EFL written discourse. In S. Granger (Ed.), Learner English on computer (pp. 107-118). London: Longman.

Recski, L. J. (2004). Expressing standpoints in EFL written discourse. Revista virtual de estudos da linguagem - ReVEL, 2(3), 1-16.

Ringbom, H. (1998). Vocabulary frequencies in advanced learner English: A cross-linguistic approach. In S. Granger (Ed.), Learner English on computer (pp. 41-52). London: Longman. 
Sundqvist, P., \& Wikström, P. (2015). Out-of-school digital gameplay and in-school L2

English vocabulary outcomes. System, 51, 65-76. doi:

https://doi.org/10.1016/j.system.2015.04.001

Swan, M. (2016). Practical English usage (4th ed.). Oxford: Oxford University Press.

Thomson, J. J. (2018). Hedging in English texts written by lower secondary pupils attending Norwegian schools. Nordic journal of modern language methodology, 6(1). Retrieved from http://journal.uia.no/index.php/NJMLM/article/view/411

Svennevig. J. \& Hasund, I.K. (2018). Uformelt talespråk [Informal spoken language]. In B.K. Mæhlum (Ed.), Norsk språkhistorie II: Praksis (pp. 119-162). NTNU: Novus forlag. Virtanen, T. (1998). Direct questions in argumentative student writing. In S. Granger (Ed.), Learner English on computer (pp. 94-106). London: Longman. 


\section{Appendix}

Complete list of textbook components and abbreviations used in citations, in alphabetical order by textbook title:

Connect (CO). 12 components:

O PB Pupil's book year 8 and 9 and 10

o TB Teacher's book year 8 and 9 and 10

o PD Pupil's digital resource year 8 and 9 and 10

o TD Teacher's digital resource year 8 and 9 and 10

- Crossroads (CR). 15 components:

o PT Pupil's textbook year 8, 9 and 10

o PW Pupil's workbook year 8, 9 and 10

o TB Teacher's book year 8, 9 and 10

o PD Pupil's digital resource year 8, 9 and 10

o TD Teacher's digital resource year 8, 9 and 10

- Enter (E). 10 components:

O PB Pupil's book year 8, 9 and 10

o BS Basic skills 8-10 (one book)

o TB Teacher's book year 8,9 and 10

o TD Teacher's digital resource year 8 and 9 and 10

- $\operatorname{Key}(\mathrm{K}) .15$ components:

o PT Pupil's textbook year 8, 9 and 10

o PW Pupil's workbook year 8, 9 and 10

o TB Teacher's book year 8, 9 and 10

o PD Pupil's digital resource year 8, 9 and 10

o TD Teacher's digital resource year 8, 9 and 10

- Lingua Planet (L). 6 components:

o PD Pupil's digital resource year 8, 9 and 10

o TD Teacher's digital resource year 8, 9 and 10

- $\quad$ New Flight (N). 12 components:

o PT Pupil's textbook year 8, 9 and 10

o PW Pupil's workbook year 8, 9 and 10

o TB Teacher's book year 8, 9 and 10

o PD Pupil's digital resource year 8, 9 and 10

- Searching (SE). 6 components:

o PB Pupil's book year 8, 9 and 10

o TB Teacher's book year 8, 9 and 10

- Stages (ST). 12 components:

o PB Pupil's book year 8, 9 and 10

o TB Teacher's book year 8,9 and 10

o PD Pupil's digital resource year 8, 9 and 10

o TD Teacher's digital resource year 8, 9 and 10

- Voices in Time (V). 12 components:

o PT Pupil's textbook year 8, 9 and 10

o PW Pupil's workbook year 8, 9 and 10

o TB Teacher's book year 8,9 and 10

o PD Pupil's digital resource year 8, 9 and 10 